\title{
Genetic prognostic markers in colorectal cancer
}

\author{
R S Houlston, I P M Tomlinson
}

Institute of Cancer Research, Sutton, Surrey, SM2 5NG, UK

Correspondence to: Dr Houlston.

Accepted for publication 11 September 1997

\begin{abstract}
The contribution of molecular genetics to colorectal cancer has been restricted largely to relatively rare inherited tumours and to the detection of germline mutations predisposing to these cancers. However, much is now also known about somatic events leading to colorectal cancer. A number of studies has been undertaken examining possible relations between genetic features and prognostic indices. While many of these studies are small and inconclusive, it is clear that a number of different pathways exist for the development of this cancer and some molecular characteristics correlate with clinicopathological features. With the advent of methods for the rapid genotyping of large numbers of colorectal cancers, it should be possible to evaluate fully the clinical usefulness of colorectal cancer genotypes through multivariate analyses. (f Clin Pathol: Mol Pathol 1997;50:281-288)
\end{abstract}

Keywords: colorectal cancer; prognosis

Colorectal cancer accounts for over $90 \%$ of the malignant tumours of the large bowel. After lung and breast cancer, it is the most common cause of death from malignant disease in western countries. The incidence of the disease in England and Wales is about 30000 cases per year, ${ }^{1}$ resulting in around 17000 deaths per annum ${ }^{2}$ and it has been estimated that at least half a million cases of colorectal cancer occur each year worldwide. ${ }^{3}$ Incidence rates of the tumour are increasing in many countries. This, together with a reduction in smoking, may result in colorectal cancer becoming the most common cause of death from malignant disease in the near future. Unfortunately, despite improvements in medical and surgical provision, there has been little change in mortality from colorectal cancer during the past 40 years. ${ }^{4}$

can either be expressed simply as degree of differentiation (well, medium, or poorly differentiated) or according to the more complex Jass grouping. ${ }^{6}$ Prognosis correlates well with both stage and grade.

Patients fall into two broad groups at time of presentation. The first group either have non-resectable cancers or disseminated disease. These patients have a very poor prognosis, with a median survival of seven months. ${ }^{3}$ The other two thirds of patients will undergo a resection of their primary tumour. Despite an apparently "curative" resection, around $50 \%$ of patients will die within five years, and of these around $80 \%$ will have had a detectable recurrence within two years. The majority of these patients die as a result of liver secondaries, but there is evidence that they also have widespread extrahepatic disease. Studies of occult hepatic metastases based on postoperative computed tomography have estimated that the mean age of deposits at time of surgery is 18 months. ${ }^{7}$ This suggests that many colorectal cancers metastasise early, but that some tumours cannot or do not metastasise, and that the factors that determine the propensity to metastasise have acted before presentation. There are many reports of the five year survival rates for colorectal cancer. Figures vary from around $20 \%$ to over $70 \%{ }^{3}{ }^{4}$ Whether these differences can be ascribed entirely to patient selection and diligent surgical resection or whether some cancers have a more inherently indolent biological behaviour remains unclear.

Clearly, improved success in the treatment of this disease requires a better understanding of its development and behaviour. Molecular studies have shown that the natural history of all colorectal cancers is not the same. In some cases, the molecular basis for the clinicopathological features of the tumour has been partially determined. If genotypic markers can be identified that correlate with tumour behaviour and patient prognosis, then this should lead to a more accurate prediction of prognosis and tailoring of treatment.

\section{Natural history of colorectal cancer}

In western countries, approximately $60 \%$ of primary colorectal cancers are situated in the rectum and sigmoid. Of the remainder, one half are located within the caecum. The tumours are staged according to Dukes's system into categories A, B, C, and D. ${ }^{5}$ Grade
Molecular genetics of colorectal cancer THE ADENOMA-CARCINOMA SEQUENCE Histological observations led to the concept that the majority of colorectal cancers develop from normal epithelium through sequentially worsening degrees of adenomatous dysplasia. ${ }^{8}$ 


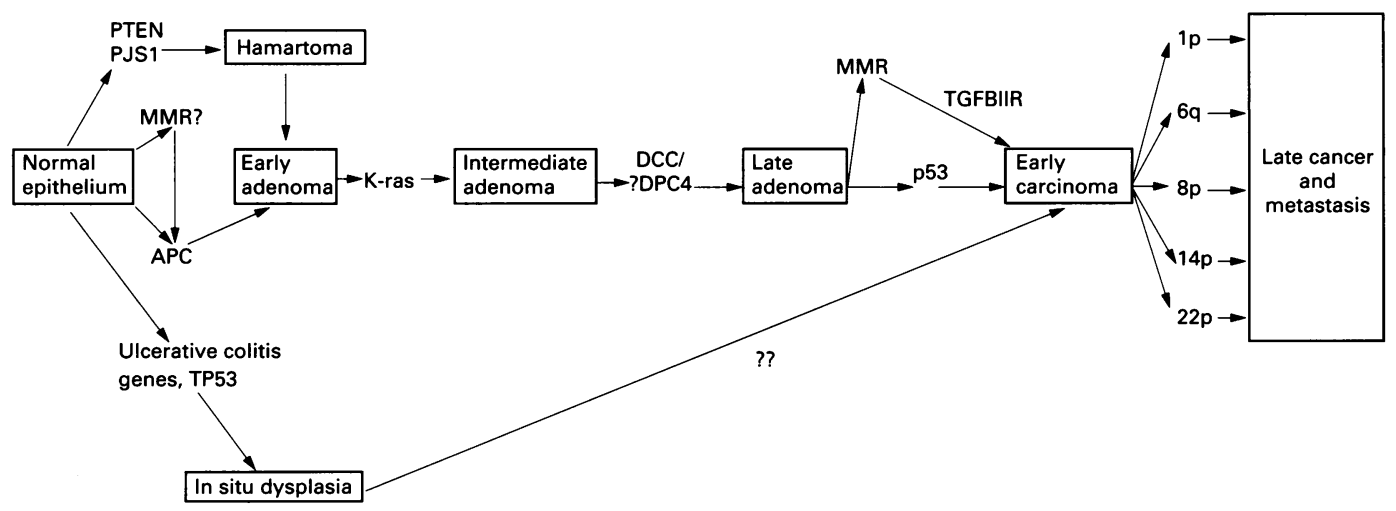

Figure 1 Genetic pathways of colorectal carcinogenesis.

The genetic pathway model for the pathogenesis of sporadic disease proposed by Fearon and Vogelstein is based on this concept of an adenoma-carcinoma sequence ${ }^{9}$ (fig 1 ). While the total accumulation of mutations is the principal factor in development of the disease, the model proposed that in most colorectal cancers the causative mutations in tumour suppressor and oncogenes occur in a particular order (specifically, adenomatous polyposis coli (APC) gene mutations, global hypomethylation, $\mathrm{K}$ ras mutations, deleted in colonic cancer (DCC) gene mutations, and finally mutations in the p53 gene). The Fearon and Vogelstein model was proposed seven years ago. Since then, other mutations that occur at a high frequency in colorectal cancer have been identified and, therefore, the original model needs to be modified. Specifically, it needs to be adapted to take account of the alternative pathways for the development of colorectal cancer that are now known to exist.

INITIATION OF COLORECTAL CARCINOGENESIS There is good evidence that only two mutations are required for the initiation of colorectal carcinogenesis. In most cases, these mutations occur at the APC tumour suppressor locus (5q21 q22). ${ }^{10-12}$ APC mutations, which generally lead to a truncated APC protein, ${ }^{13}$ or take the form of allele loss, ${ }^{14}$ are detected in about $75 \%$ of sporadic colorectal cancers, ${ }^{15}$ and are seen in the earliest adenomas from which these cancers develop. ${ }^{10}$ In addition to the role of the APC gene in the aetiology of sporadic colorectal cancer, germline mutations in this gene cause familial adenomatous polyposis coli (FAP), which is characterised by florid gastrointestinal adenomas and many extra colonic features.

The APC protein is probably a dimer.$^{16}$ It is likely that the gene product exerts its tumour suppressor actions through intracellular signalling, interactions with the cytoskeleton, and controlling cellular proliferation, possibly affecting the rate of cell division or apoptosis. ${ }^{17-22}$

Whether APC mutations are always the first events in colorectal carcinogenesis or whether germline defects in one of the mismatch repair (MMR) genes could provide an alternative initiating step has been questioned. Mutations in four MMR genes cause the dominantly inherited syndrome hereditary non-polyposis colorectal cancer (HNPCC): hMSH2 on chromo- some $2 \mathrm{p}, \mathrm{hMLH} 1$ on chromosome $3 \mathrm{p}$, hPMS 1 on chromosome $2 \mathrm{q}$, and hPMS2 on chromosome $7 q^{23-26}$ Colorectal cancers from patients with mutations in these MMR genes consistently show microsatellite instability, a form of replication error. Although, in general, it is assumed that mutations in the MMR genes in HNPCC families act only to increase the mutation rate (including mutations at APC), it is also possible that the MMR mutations themselves may have a direct role in initiation of tumorigenesis. MMR mutations also occur in sporadic colorectal cancers ${ }^{27}$; however, when these mutations arise somatically they occur after APC mutations and, therefore, are involved in the progression of tumours, rather than initiation. ${ }^{28}$

Colorectal cancers associated with ulcerative colitis do not usually develop from adenomas, ${ }^{29}$ suggesting a different genetic pathway from sporadic cancers. ${ }^{30}$ The low frequency of APC mutations in colorectal cancers associated with inflammatory bowel disease suggests that mutations in this gene are not the initiating event in these types of tumours. ${ }^{31-33}$

The possibility that mutations in other genes can initiate colorectal tumorigenesis is suggested by reports of adenoma families not linked with APC. ${ }^{34}$ In addition, evidence is emerging that a hamartoma-adenomacarcinoma sequence exists ${ }^{35}$ and genes for several hamartoma syndromes have been localised or cloned (such as Peutz Jeghers syndrome on chromosome 19q (PJS1), ${ }^{36}$ some forms of juvenile polyposis, ${ }^{37}$ and Cowden's syndrome/ PTEN on chromosome $10^{38}$ ). Furthermore, there is some support for a hyperplastic polypadenoma-carcinoma sequence ${ }^{39}$ (fig 1 ).

\section{COLORECTAL CANCER PROGRESSION: EARLY}

ADENOMA TO CARCINOMA

While mutations in the APC gene initiate events in colorectal tumorigenesis, it is most likely that these mutations alone are insufficient for adenomas to progress and without mutations at other loci, regression might occur. ${ }^{4041}$ Probably, several genes are involved in the progression of early adenomas to early carcinomas.

Early candidates for adenoma progression were the ras oncogenes. The $\mathrm{K}$ ras gene is one of a family of three human genes ( $\mathrm{K}$ ras, $\mathrm{H}$ ras, and $\mathrm{N}$ ras). ${ }^{42}$ These encode small GTP binding proteins localised on the inner leaflet of the cell 
membrane that are involved in transducing signals from receptor tyrosine kinases such as epidermal growth factor receptor (EGFR). The receptors are coupled to the ras proteins through an intermediate complex of GRB and SOS2 proteins. Downstream elements of this transduction pathway include the cytoplasmic RAF serine threonine kinase and mitogen activated protein (MAP) kinase cascades. The ras proteins are activated on binding GTP and deactivated by intrinsic GTPase activity from two GTPase activating (GAP) proteins. One of these is ras-GAP-p120 and the other is neurofibromin, the product of the NF1 gene. The ras oncogenes are activated by point mutations that prevent the activation of GTPase. ${ }^{42}$ More than $50 \%$ of colorectal cancers display specific mutations in the $\mathrm{K}$ ras gene, with an increasing frequency of mutation in larger and more advanced lesions. ${ }^{43}$ The consequence of $\mathrm{K}$ ras mutations during tumour development may be a growth advantage of those cells with both APC and $K$ ras mutations over cells with APC mutations alone. Although $\mathrm{K}$ ras mutations are seen within histologically normal mucosa, ${ }^{44}$ they appear to be present with coexisting APC mutations only in dysplastic mucosa. ${ }^{45} 46$ This supports the notion that $\mathrm{K}$ ras mutations confer no growth advantage in the absence of a mutation in the APC gene.

Originally, the MCC (mutated in colonic cancer) and DCC tumour suppressor genes were thought to play a role in colorectal carcinogenesis. In the model of Fearon and Vogelstein, mutation at the DCC locus represented the third step in the genetic pathway. ${ }^{9}$ The MCC and DCC genes were identified as a result of the frequent allele loss close to their locations on $5 \mathrm{q} 21-\mathrm{q} 22$ and $18 \mathrm{q} 21.3$, respectively, in colorectal cancers. ${ }^{47}{ }^{48} \mathrm{~A}$ small number of mutations at MCC were described originally in these tumours, ${ }^{49}$ but subsequent studies have found very few mutations, suggesting that APC is the primary target for allele loss on $5 \mathrm{q} 21-\mathrm{q} 22 .^{50}$ DCC is a neural cell adhesion molecule homologue and, therefore, its mutation may have a role in colorectal tumour progression, invasion, and metastasis (although, in general, allele loss at DCC occurs before malignancy). However, there is now evidence suggesting that another gene, DPC4, may be the target of allele loss on chromosome $18 \mathrm{q}$ in some tumours. ${ }^{51}$

There is no doubt about the role of p53 mutations in the progression of colorectal tumours. $\mathrm{p} 53$ protein is important in maintaining DNA integrity. DNA damage results in p53 mediated arrest in the $G_{1}$ phase of the cell cycle, followed by repair or, if the damage is too great, p53 induced apoptosis. Therefore, loss of function of $\mathrm{p} 53$ by mutation or deletion allows cells to accumulate mutations throughout the genome and results in karyotypic instability, impaired $G_{1}$ cell cycle arrest, and reduced apoptosis. ${ }^{52-55}$ Mutations in the p53 gene occur in approximately $75 \%$ of colorectal cancers, but the frequency is lower in carcinomas that are mucinous and those that arise in the proximal colon, as is seen in HNPCC. p53 mutations are rare in adenomas, suggesting that $\mathrm{p} 53$ plays a role in tumour progression, but it is not an absolute requirement for malignant transformation because a significant proportion of cases have no demonstrable abnormality. These mutations also tend to occur at the late adenoma stage (although they occur earlier in colorectal cancers associated with inflammatory bowel disease, which do not develop from adenomas). ${ }^{56}$ Dominant, gain of function mutations in p53 are common in colorectal cancers and these can be detected reliably using immunohistochemistry for p53 protein. ${ }^{57}{ }^{58}$ Allele loss close to p53 (17p13.1) also occurs frequently, ${ }^{56}$ either because of loss of the wild-type allele or possibly because another gene nearby is targeted.

The sites of other candidate tumour suppressor genes that may be involved in colorectal tumour progression have been identified by allele loss studies. Mutations of the FHIT gene $^{59}$ and at the p16 (MTS1) locus ${ }^{60-62}$ may be important in colorectal tumours, the latter through failure of cell cycle arrest. Locations of other tumour suppressor loci include chromosomes $1 \mathrm{p}^{6364}$ (close to the putative human Mom-1 homologue), $6 \mathrm{q}^{65}{ }^{65} 8 \mathrm{p},{ }^{667} 14 \mathrm{q},{ }^{68}$ and 22 q $^{69}$ Typically, allele loss occurs at these locations at frequencies between $30 \%$ and $60 \%$.

The roles of MMR mutations in colorectal tumorigenesis have been mentioned briefly. In HNPCC tumours, one mutation is inherited and the other occurs somatically. In about $15 \%$ of sporadic colonic cancers, two MMR mutations (or two mutations at a related locus) occur in the soma. ${ }^{70}$ Normal mucosa from HNPCC patients does not display microsatellite instability, only $50 \%$ of HNPCC adenomas (compared with $90 \%$ of cancers) exhibit microsatellite instability, and the frequency of early lesions such as APC mutations is similar in replication error positive and negative tumours. $^{71} 72$ Therefore, in sporadic cancers, defective MMR function may be an alternative route to allele loss or the acquisition of mutations, and loss of MMR may simply "catalyse" the progress of a tumour down the same pathway as microsatellite instability negative cases. MMR mutations may act as alternatives to p53 mutations in colorectal tumours, albeit through a different mechanism. Although genomic instability in p53 mutant cancers tends to take the form of karyotypic abnormalities, instability resulting from MMR mutations can lead to near diploid lesions. It has been found that MMR mutations are associated negatively with mutant $\mathrm{p} 53$ and that, like p53 mutations, MMR mutations often occur in late colonic adenomas. ${ }^{72}{ }^{73}$ Genomic instability may also be caused by somatic or germline mutations in other genes involved in DNA replication and repair. Support for this idea comes from a study of two apparently sporadic colorectal cancer cases that were both shown to carry DNA polymerase $\gamma$ variants. ${ }^{74}$

\section{MALIGNANCY}

Few genetic changes specific to mature colorectal cancers have been identified. Several regions of allele loss have been detected but 
their roles in tumour progression are unclear. The types of mutations that would be important in the mature colorectal cancer are those that cause sustained replication, decreased apoptosis, or angiogenesis. Malignancy requires colorectal tumour cells to exhibit several features, namely the ability to: (a) erode the basement membrane, (b) disrupt normal cell junctions, and (c) survive in the blood or lymphatic systems and in a new tissue environment.

Cell adhesion molecules are candidates for involvement in the process of invasion and metastasis of colorectal cancers. In addition to effects on adhesion, mutations at these loci may also have effects on growth. For example, E cadherin forms part of the adherens junction complex of epithelial cells. Loss of the $E$ cadherin protein occurs in several cancers, including colorectal cancer, and is associated with the development of invasive properties. ${ }^{75-77}$ Other proteins that may be associated with invasion by colorectal cancers include those involved in tissue degradation, such as urokinase plasminogen activators and matrix metalloproteinases/collagenases. ${ }^{78} 79$ The cells of metastases may have genotypes and/or patterns of gene expression distinct from those of primary tumours. Variation at a number of gene loci may alter the behavioural pattern of the mature colorectal cancer. These include the NM23 gene, which has a possible role in the metastasis of several cancers, and CD44. ${ }^{80-85}$

\section{Clinicopathological correlations: prediction of prognosis}

The recognition that there are probably several different genetic pathways for the development of colorectal cancer suggests that correlations exist between the molecular and clinicopathogical features of tumours that are not apparent using routine methods such as histology. These correlations may serve as prognostic determinants and/or enable the partitioning of patients into groups for different therapies. A number of studies have sought to examine the relation between genotypic variation in these tumours and clinicopathological features, especially patient prognosis. Most work has been in the form of case control studies, using a comparison of the frequency of genotypes in primary and secondary tumours as a surrogate for survival. However, a small number of studies have examined the relation between genotype and prognosis by classical survival analysis. In this section, we review the evidence for genetic variation in colorectal cancers as markers of prognosis, including some studies of protein or mRNA expression that have been assumed to be indicators of underlying mutations.

\section{ALLELE LOSS STUDIES}

In an early allelotyping study based upon 56 patients, Vogelstein et al showed that patients with more than the median percentage of allelic deletions had a considerably worse prognosis than other patients; based on a mean follow up period of 38 months, the tumour recurrence and death rates were $30 \%$ and $68 \%$, and $26 \%$ and $64 \%$, respectively. ${ }^{86}$ Later studies have examined the relation between specific chromosome abnormalities and tumour behaviour.

Chromosome $18 \mathrm{q}$ allele loss has a well 3 established association with colorectal cancer 음 progression and has been evaluated as a prognostic marker in a number of studies. ${ }^{47} 87-90$ ? Overall, its value may not be great. However, $\overrightarrow{\vec{D}}$ based on more than 100 patients with stage II and III cancers it appears that allele loss at this $\frac{C}{0}$ region represents a significant prognostic $\overline{\frac{m}{5}}$ marker. ${ }^{47}$ After adjustment for tumour differ- $\bar{\Phi}$ entiation, vein invasion, and stage it has been shown to be a strong predictor for survival with a hazard ratio for death of 2.5 (95\% confidence? interval $(\mathrm{CI}), 1.1$ to $5.7, \mathrm{p}=0.036) .^{47}$

Cytogenetic and allele loss studies of chro- $\stackrel{\omega}{\Omega}$ mosome 17 have been based on fewer patients $\overline{3}$ than the analyses of chromosome $18 .^{87}{ }^{90-92} \mathrm{ir}$ Most have found that both $17 \mathrm{p}$ and $17 \mathrm{q}$ \% anomalies are associated with invasion and $\tilde{\infty}_{\infty}$ metastasis and allele loss at $17 \mathrm{q}$ has also been shown to provide independent prognostic information. ${ }^{92}$

Mutations that are likely to be important $\mathbb{D}$ prognostically are those that involve genes $\overparen{\mathscr{D}}$ involved in tumour progression rather than ini- $\frac{}{0}$ tiation. Therefore, it is not surprising that allele $\frac{\mathbb{D}}{-}$ loss at chromosome $5 \mathrm{q}$, the site of the APC $\overrightarrow{0}$ gene, has not been shown to be a prognostic. marker. ${ }^{878890}$ The high rate of allele loss at other chromosomes such as $8 \mathrm{p}, 1 \mathrm{p}$, and $11 \mathrm{q} \sum^{\circ}$ during tumour progression suggests that they may be sites of other tumour suppressor genes that are important for the progression of $\stackrel{\mathbb{Q}}{\mathscr{Q}}$ colonic tumours. A correlation between $8 \mathrm{p} \underset{\overrightarrow{0}}{\overrightarrow{0}}$ allele loss and microinvasion (a prognostic 3 marker independent of Dukes's stage) has been reported $^{93}$ in one small study of 14 colorectal cancers. A relation between tumour progres- 3 sion and chromosome 1 deletions has also been? shown. ${ }^{87}$ However, analysis of 126 sporadic colorectal cancers for allele loss at $11 \mathrm{q} 22$ has failed to show an association with Dukes's grade or degree of differentiation. ${ }^{94}$

K RAS

Along with $\mathrm{p} 53, \mathrm{~K}$ ras mutations are one of the most common genetic lesions in human cancer. Since the discovery of the human ras gene family, there has been much debate $\omega$ concerning the potential for differential tumour behaviour as a result of different ras? mutations. Point mutations in codons $12,13, \stackrel{\oplus}{\oplus}$ and 61 of the $K$ ras gene are early events in the pathogenesis of colorectal cancer. However, the impact of the number, type, and position of such mutations on the progression of adeno- $\mathbb{D}$ mas, as well as the clinical behaviour of colorectal carcinomas, is not fully established. To date, most studies have indicated that the second base of codon 12 is mutated more heavily in colorectal cancers than the first oro the third bases. Therefore, it is conceivable that the type of $\mathrm{K}$ ras mutation determines tumour behaviour directly.

In a relatively large study by Finkelstein et al of 194 consecutive primary, recurrent, and metastatic colorectal adenocarcinomas, a significantly higher mutation rate in $\mathrm{K}$ ras was 
seen in lymphogenous, haematogenous metastases. ${ }^{95}$ When colorectal carcinomas were analysed by specific $\mathrm{K}$ ras mutation type, it was found that codon 13 mutated tumours did not progress to local or distant metastasis. Tumours having a codon 12 valine substitution did not metastasise beyond pericolonic, perirectal lymph nodes. In contrast, colorectal cancers with codon 12 aspartic acid substitutions accounted for most of the distant haematogenous deposits. Tumours with normal $\mathrm{K}$ ras accounted for most intraperitoneal deposits. On the basis of these data, Finkelstein et al proposed that genotyping of colorectal adenocarcinoma by $\mathrm{K}$ ras status would identify subsets of patients likely to pursue indolent or aggressive forms of disease.

Some, but not all, reports have supported the proposal that the possession of a $K$ ras mutation is associated independently with shorter survival rates. ${ }^{96-100}$ However, the relation between specific mutation and prognosis is unclear. Early in vitro observations suggested that codon $12 \mathrm{~K}$ ras mutations elicited stronger transformation responses than codon $13 \mathrm{~K}$ ras changes in NIH/3T3 cell assays. ${ }^{101-103}$ However, this notion has not been supported by some biochemical analyses of different ras proteins. ${ }^{104-106}$ On the basis of the available clinicopathological data in colorectal cancer, it is likely that patient survival is related to the occurrence of $\mathrm{K}$ ras mutations, but is not necessarily related to the specific type of mutation.

DELETED IN COLON CANCER

If allelic loss of chromosome $18 \mathrm{q}$ predicts a poor outcome in colorectal cancer then the DCC gene must be a prime candidate for the cause of this association. In a single study of 132 patients with curatively resected stage II and III colorectal carcinomas, ${ }^{107}$ the expression of DCC protein was a strong positive predictive factor for survival. Patients with stage II disease whose tumours expressed DCC, had a five year survival rate of $94.3 \%$ compared with a survival rate of $62 \%$ for patients with DCC negative tumours. In patients with stage III disease, the survival rates were $59 \%$ and $33 \%$ for patients with DCC positive and negative tumours, respectively.

MISMATCH REPAIR GENES AND MICROSATELLITE INSTABILITY

Evidence directly correlating molecular and clinicopathological data for colorectal cancer has come from HNPCC. Colorectal cancers developing in carriers of HNPCC mutations are poorly differentiated and frequently multiple. Paradoxically, despite multiplicity and poor differentiation of cancers, early observations suggested that colorectal cancers in HNPCC carried a more favourable prognosis that in sporadic cases. Convincing evidence for improved survival in HNPCC is provided by a large study from Finland. ${ }^{108}$ The survival rates of 175 colorectal cancer patients with HNPCC were compared with those of 14000 patients with sporadic colorectal cancers diagnosed before the age of 65 years. One hundred and twenty of the patients with HNPCC came from families segregating a germline mutation in the hMLH1 gene. The overall survival rate was $65 \%$ for patients with HNPCC and $44 \%$ for patients with sporadic cancer. Furthermore, the survival rates of HNPCC patients were better in all strata analysed. A similar study has been undertaken in Japan. ${ }^{109}$ The five year survival rate for colorectal cancer in patients from families conforming to the Amsterdam criteria for $\operatorname{HNPCC}(n=14)$ was $92 \%$, in putative HNPCC families $(n=131)$ the survival rate was $70 \%$, while in sporadic colorectal cancer ( $n=1604$ ) the survival rate was $60 \% .^{109}$

To determine whether microsatellite instability characterises a subset of sporadic colorectal cancers as well as patients with HNPCC, Ishimari et al examined its incidence in 80 primary colorectal cancers and 36 liver metastases. ${ }^{110}$ The replication error phenotype did not show correlation with any clinicopathological parameters of tumour aggressiveness, such as Dukes's staging, histological grade, or survival suggesting that the microsatellite instability phenotype is not associated with aggressiveness.

A systematic analysis of 215 sporadic colorectal cancer patients showed that those with microsatellite instability had a survival advantage over patients without it, independent of other prognostic factors. ${ }^{111}$ Microsatellite instability was found in $16.4 \%$ of colorectal cancers. The hazard ratio of patients with tumours showing microsatellite instability to those without was estimated to be 0.39 (95\% CI 0.19 to 0.82 ). At any point in time after diagnosis, a patient whose tumour displayed microsatellite instability had a risk of dying, which was approximately $39 \%$ of the risk of a patient with a tumour without microsatellite instability, even after allowing for the effect of other predictive factors. Only one of the 24 patients exhibiting microsatellite instability in their colorectal cancers possessed a detectable germline defect in $\mathrm{hMSH} 2$. These findings suggest that although the genetic basis of HNPCC and sporadic cancers with microsatellite instability is different, tumours in the two groups share some biological characteristics in terms of prognosis.

P53 AND P27

An increased intracellular concentration of p53, which is frequently but not always related to p53 mutation, has been proposed as being associated with poor prognosis in some tumour types. In immunohistochemical studies of colorectal cancer, although p53 overexpression correlates with chromosome $17 \mathrm{p}$ loss, hyperdiploid DNA content, and tumour site there have been conflicting findings about its role as a prognostic indicator. ${ }^{112-125}$ This reflects the fact that the degree of association between p53 mutations and protein expression depends, in part, on the specific antibody used. In studies of the relation between p53 mutations and prognosis, the situation is much clearer. Studies suggest strongly that colorectal cancers harbouring p53 mutations are more aggressive, are associated with a higher propensity for 
lymphatic and haematogenous spread, and have a worse prognosis. ${ }^{126-132}$

p27 is a member of the cip/kip family of cyclin dependent kinase inhibitors, which bind to cyclin:cyclin dependent kinase (cdk) complexes and block progression through the cell cycle. p27 regulates progression from $G_{1}$ into $S$ phase by binding to and inhibiting the cyclin $\mathrm{E} / \mathrm{Cdk} 2$ complex, which is required for cells to enter $S$ phase. In contrast to the p53 gene, mutations in p27 are rare. However, cell cycle regulation of $\mathrm{p} 27$ concentrations occurs at the post-transcriptional level through proteasome mediated degradation. ${ }^{133}$ Recently, reduced expression of p27 has been shown to correlate with poor survival in a study of 149 patients with primary colorectal cancer. ${ }^{134}$ Patients whose tumours expressed p27 had a median survival of 151 months, whereas those who lacked p27 (10\%) had a median survival of only 69 months. In this study, p27 expression was shown to be an independent prognostic marker and the risk of death associated with reduced expression was increased 2.9-fold.

\section{Conclusions}

The incidence of colorectal cancer is increasing and, unfortunately, the prognosis remains poor for the majority of patients. Identification of patients who are at a high risk of recurrent local and metastatic disease is important for the selection of appropriate treatment. Prognostic variables that have been found to be statistically significant include pathological stage and grade, type of tumour growth, chromosomal aneuploidy, and the presence of microinvasion. Until recently, there has been little understanding of the molecular basis of these indices. Despite the continuing use of histopathology as the gold standard, in the future, the genetic features of colorectal tumours will almost certainly become useful indicators of prognosis and of the most appropriate therapy. To date, one of the problems with clinicomolecular associations has been that most studies have, for entirely understandable reasons, analysed only small numbers of tumours. However, there is some evidence that colorectal cancers harbouring defects in the MMR genes are associated with a better prognosis and those with chromosome anomalies, such as deletion of $18 \mathrm{q}$ or $17 \mathrm{q}$ and mutations in $\mathrm{K}$ ras and $\mathrm{p} 53$, a worse prognosis. With the advent of methods for rapid genotyping it should be possible to construct mutation profiles of tumours and use multivariate analysis to determine which molecular features correlate with the clinicopathological data.

1 HMSO. Cancer statistics. Registrations. England and Wales. London: HMSO, 1989

2 HMSO. Mortality statistics. Cause. England and Wales. London: HMSO, 1992.

3 Finlay IG, Pickford IR. Colorectal carcinoma. In: Lawson $\mathrm{DH}$, ed. Current medicine, 4th edn. Edinburgh: Chruchill Livingstone, 1994:51-64

4 Beart RW, Steele GJ, Menck HR, Chmiel JS, Ocwieja KE, Winchester DP. Management and survival of patients with adenocarcinoma of the colon and rectum: a national survey of the Commission on Cancer. $\mathcal{F}$ Am Coll Surg 1995;181: 225-36.

5 Dukes CE, Bussey HJR. The spread of cancer and its effect on prognosis. Cancer 1958;12:309-20.
6 Jass JR, Love SB, Northover JMA. A new prognostic classification of rectal cancer. Lancet 1987;ii: 1303-6.

7 Finlay IG, Meck D, Bruton F, et al. Growth rate of hepatic metastases in colorectal cancer. Br F Surg 1988;75:641-4.

8 Morson B, Dawson I, Day D, Jass J, Price A, Williams G. Morson and Dawson's gastrointestinal pathology, 3rd edn

9 Fearon ER, Vogelstein B. A genetic model for colorectaro tumorigenesis. Cell 1990;61:759-67.

10 Powell SM, Zilz N, Beazer Barclay Y, et al. APC mutations occur early during colorectal tumorigenesis. Nature 1992:359:235-7

11 Groden J, Thliveris A, Samowitz W, et al. Identification and characterization of the familial adenomatous polyposis cole gene. Cell 1991;66:589-600.

12 Kinzler KW, Nilbert MC, Su LK, et al. Identification of FAI locus genes from chromosome 5q21. Science 1991;253 $661-5$.

13 Miyoshi Y, Nagase H, Ando H, et al. Somatic mutations of the APC gene in colorectal tumors: mutation cluster regiorn in the APC gene. Hum Mol Genet 1992;1:229-33.

14 Solomon E, Voss R, Hall V, et al. Chromosome 5 allele los $\overrightarrow{0}$ in human colorectal carcinomas. Nature 1987;328:616-9.

15 Miyaki M, Konishsi M, Kikuchi Yanoshita R, et al. Charac $\vec{\omega}$ teristics of somatic mutation of the adenomatous polyposio coli gene in colorectal tumours. Cancer Res 1994;54:3011 20.

16 Joslyn G, Richardson DS, White R, Alber T. Dimer formair tion by an $\mathrm{N}$ terminal coiled coil in the APC protein. Proo Natl Acad Sci USA 1993;90:11109-13.

17 Baeg GH, Matsumine A, Kuroda T, et al. The tumour sup N pressor gene product APC blocks cell cycle progressior from $G 0 / G 1$ to $S$ phase. $E M B O \mathcal{F} 1995 ; 14: 5618-25$

18 Su LK, Vogelstein B, Kinzler KW. Association of the APC음 tumor suppressor protein with catenins. Science 1993;262. 1734-7.

19 Rubinfeld B, Souza B, Albert I, et al. Association of the APC gene product with beta catenin. Science 1993;262:1731-4@

20 Browne S, Williams A, Hague A, Butt A, Paraskeva C Los of apc protein expressed by human colonic epithelial cell and the appearance of a specific low molecular weight form is associated with apoptosis in vitro. Int $\mathcal{F}$ Cancer 1994;59:56-64

21 Burchill SA. The tumour suppressor APC product is associe ated with cell adhesion. Bioessays 1994;16:225-7.

22 Munemitsu S, Souza B, Muller O, Albert I, Rubinfeld BD Polakis P. The APC gene product associates with microtubules in vivo and promotes their assembly in vitro. Cances Res 1994;54:3676-81.

23 Leach FS, Nicolaides NC, Papadopoulos N, et al Mutations of a mutS homolog in hereditary nonpolyposio colorectal cancer. Cell 1993;75:1215-25.

24 Lindblom A, Tannergard P, Werelius B, Nordenskjold $M$ Genetic mapping of a second locus predisposing to heredio tary non polyposis colon cancer. Nat Genet 1993;5:279-82马

25 Fishel R, Lescoe MK, Rao MR, et al. The human mutator gene homolog MSH2 and its association with hereditar nonpolyposis colon cancer. Cell 1993;75:1027-38.

26 Aaltonen LA, Peltomaki P, Leach FS, ct al. Clues to the pathogenesis of familial colorectal cancer. Science 1993: 260:812-16.

27 Liu B, Nicolaides NC, Markowitz S, et al. Mismatch repair gene defects in sporadic colorectal cancers with microsatel lite instability. Nat Genet 1995;9:48-55.

28 Tomlinson IPM, Novelli MR, Bodmer WF. The mutation rate and cancer. Proc Natl Acad Sci USA 1996;93:14800-3?

29 Connell WR, Talbot IC, Harpaz N, et al. Clinicopathologio cal characteristics of colorectal carcinoma complicating ulcerative colitis. Gut 1994;35:1419-23.

30 Ilyas $M$, Tomlinson IPM. Genetic pathways in colorecta? cancer. Histopathology 1996;28:389-99.

31 Redston M, Papadopoulos N, Caldas C, Kinzler K, Kern S Common occurrence of $\mathrm{APC}$ and $\mathrm{K}$ ras mutation in the spectrum of colitis associated neoplasias. Gastroenterolog $\mathbb{N}$ 1995;108:383-92.

32 Tarmin L, Yin J, Harpaz N, et al. Adenomatous polyposis coli gene mutations in ulcerative colitis associated dyspla sias and cancers versus sporadic colon neoplasms. Cancer Res 1995;55:2035-8.

33 Brentnall TA, Crispin DA, Rabinovitch PS, et al. Mutations in the p53 gene: an early marker of neoplastic progression in ulcerative colitis. Gastroenterology 1994;107:369-78.

34 Tops CM, van der Klift HM, van der Luijt RB, et al. Non allelic heterogeneity of familial adenomatous polyposis. $A n \mathrm{~g}$ f Med Genet 1993;47:563-7.

35 Whitelaw SC, Murday VA, Tomlinson IPM, et al. Clinicas and molecular features of the hereditary mixed polyposis syndrome. Gastroenterology 1997;112:327-34.

36 Hemminki A, Tomlinson I, Markie D, Jarvinen H, Sistonen P, Bjorkqvist AM, et al. Localization of a susceptibility locus Por Peutz Jeghers syndrome to $19 \mathrm{p}$ using comparative for Peutz Jeghers syndrome to $19 \mathrm{p}$ using comparative genomic hybridization and targeted linkage analysis. Nak

37 Jacoby RF, Schlack S, Cole CE, Marshall DJ, Kuhlman G, e함 al. Identification of a juvenile polyposis tumor suppressor? gene locus (JP1) and demonstration of its deletion in sub epithelial cells [abstract]. Gastroenterology 1996;110:A535.

38 Liaw D, Marsh DJ, Li J, et al. Germline mutations of th PTEN gene in Cowden disease, an inherited breast and thyroid cancer syndrome. Nat Genet 1997;16:64-7.

39 Jeevarathnam P, Cottier DS, Browett PJ, Vanderwater NS, Pokos V, Jass JR. Familial giant hyperplastic polyposis predisposing to colorectal cancer-a new hereditary bowel cancer syndrome. $\mathcal{7}$ Pathol 1996;1 179:20-5. 
40 Shepherd JA. Regression phenomenon in familial polyposis. Proc R Soc Med 1972;65:169.

41 Giardello FM. Sulindac and polyp regression. Cancer Metastasis Rev 1994;13:279-83.

42 Bos JL. The ras gene family and human carcinogenesis. Mutat Res 1988;195:255-71.

43 Smith AJ, Stern HS, Penner M, et al. Somatic APC and K ras codon 12 mutations in aberrant crypt foci from human colons. Cancer Res 1994;54:5527-30.

44 Minamoto T, Yamashita N, Ochiai A, et al. Mutant K ras in apparently normal mucosa of colorectal cancer patients. Its potential as a biomarker of

45 Pretlow TP. Aberrant crypt foci and $\mathrm{K}$ ras mutations: earliest recognised players or innocent bystanders in colon carcinogenesis? Gastroenterology 1995;108:600-3.

46 Bird RP. Role of aberrant crypt foci in understanding the pathogenesis of colon cancer. Cancer Lett 1995;93:55-71.

47 Jen J, Kim H, Piantadosi S, et al. Allelic loss of chromosome $18 \mathrm{q}$ and prognosis in colorectal cancer. $N$ Engl $f \mathrm{Med}$ 1994;331:213-21.

48 Vogelstein BV, Fearon ER, Hamilton SR, et al. Genetic alterations during colorectal tumour development. $N$ Engl $\mathcal{F}$ Med 1988;319:525-32.

49 Kinzler KW, Nilbert MC, Vogelstein B, et al. Identification of a gene located at chromosome 5q21 that is mutated in colorectal cancers. Science 1991;251:1366-70.

50 Curtis LJ, Bubb VJ, Gledhill S, Morris RG, Bird CC, Wyllie $\mathrm{AH}$. Loss of heterozygosity of MCC is not associated with mutation of the retained allele in sporadic colorectal mutation of the retained allele in

51 Hahn SA, Hoque AT, Moskaluk CA, et al. Homozygous deletion map at 18q21.1 in pancreatic cancer. Cancer Res 1996;56:490-4.

52 Lane DP. Cancer. p53, guardian of the genome. Nature 1992;358:15-6.

53 Donehower LA, Bradley A. The tumor suppressor p53. Biochim Biophys Acta 1993;1155:181-205.

54 Carder P, Wyllie AH, Purdie CA, et al. Stabilised p53 facilitates aneuploid clonal divergence in colorectal cancer. Oncogene 1993;8:1397-401.

55 Krawczak M, Smith SB, Schmidtke J, Kakkar VV, Cooper DN, Hovig E. Somatic spectrum of cancer associated single basepair substitutions in the $\mathrm{p} 53$ gene is determined mainly by endogenous mechanisms of mutation and by selection. Hum Mutat 1995;5:48-57.

56 Baker SJ, Preisinger AC, Jessup JM, et al. p53 gene mutations occur in combination with $17 \mathrm{p}$ allelic deletions as late events in colorectal tumorigenesis. Cancer Res 1990; as late events

57 Cunningham J, Lust JA, Schaid DJ, et al. Expression of p53 and allelic loss in colorectal carcinoma. Cancer Res 1992;52:1974-80.

58 Kawasaki Y, Monden T, Morimoto $\mathrm{H}$, et al. Immunohistochemical study of p53 expression in microwave fixed, paraffin embedded sections of colorectal carcinoma and adenoma. Am $\mathcal{~}$ Clin Pathol 1992;97:244-9.

59 Ohta $\mathrm{M}$, Inoue H, Cotticelli MG, et al. The FHIT gene, spanning the chromosome 3 p14.2 fragile site and renal carcinoma associated $t(3,8)$ breakpoint, is abnormal in digestive tract cancers. Cell $1996 ; 84: 587-97$.

60 Okamoto A, Demetrick DJ, Spillare EA, et al. Mutations and altered expression of p16חNK4 in human cancer. Proc Natl Acad Sci USA 1994;91:1 1045-9.

61 Herman JG, Merlo A, Mao L, et al. Inactivation of the CDKN2/p16/MTS1 gene is frequently associated with aberrant DNA methylation in all common human cancers. Cancer Res 1995;55:4525-30.

62 Gonzalez ZM, Bender CM, Yang AS, et al. Methylation of the 5' CpG island of the p16/CDKN2 tumor suppressor gene in normal and transformed human tissues correlates with gene silencing. Cancer Res 1995;55:4531-5.

63 Leister I, Weith A, Bruderlein S, et al. Human colorectal cancer: high frequency of deletions at chromosome $1 \mathrm{p} 35$. Cancer Res 1990;50:7232-5.

64 Praml C, Finke LH, Herfarth C, Schlag P, Schwab M, Amler L. Deletion mapping defines different regions in $1 \mathrm{p} 34.2$ pter that may harbor genetic information related to 1p34.2 pter that may harbor genetic information related

65 Wildrick D, Alfaro S, Gope R, Boman B. A study of chromosome 6 allele loss in human colorectal carcinomas. Anticancer Res 1992;12:1717-19.

66 Fujiwara Y, Emi M, Ohata H, et al. Evidence for the presence of two tumor suppressor genes on chromosome 8p for colorectal carcinoma. Cancer Res 1993;53:1172-4.

67 Cunningham C, Dunlop MG, Wyllie AH, Bird CC. Deletion mapping in colorectal cancer of a putative tumour suppressor gene in 8p22-p21.3. Oncogene 1993;8:1391-6.

68 Young J, Leggett B, Ward M, et al. Frequent loss of heterozygosity on chromosome 14 occurs in advanced colorectal zygosity on chromosome 14 occurs in

69 Yana I, Kurahashi H, Nakamori S, et al. Frequent loss of heterozygosity at telomeric loci on $22 \mathrm{q}$ in sporadic colorectal cancers. Int $\mathcal{f}$ Cancer 1995;60:174-7.

70 Liu B, Parsons R, Papadopoulos N, et al. Analysis of mismatch repair genes in hereditary non polyposis colorectal cancer patients. Nat Med 1996;2:169-74.

$71 \mathrm{Kim} \mathrm{H}$, Jen J, Vogelstein B, Hamilton SR. Clinical and pathological characteristics of sporadic colorectal carcinomas with DNA replication errors in microsatellite sequences. Am $\mathcal{F}$ Pathol 1994;145:148-56.

72 Young J, Leggett B, Gustafson C, et al. Genomic instability occurs in colorectal carcinomas but not in adenomas. Hum Mutat 1993;2:351-4.
73 Ilyas M, Tomlinson IPM, Novelli MR, Hanby A, Bodmer WF, Talbot IC. Clinico pathological features and p53 expression in left sided sporadic colorectal cancers with and without microsatellite instability. $\mathcal{F}$ Pathol 1996;179: 370-5.

74 da Costa LT, Liu B, El Deiry WS, Hamilton SR, Vogelstein $\mathrm{B}$, Markowitz S, et al. Polymerase and variants in RER colorectal tumours. Nat Genet 1995;9:10-1.

75 Linn SC, Giaccone G. MDR1/P glycoprotein expression in colorectal cancer. Eur $\mathcal{F}$ Cancer 1995;31 A:1291-4.

76 Nuovo GJ. In situ PCR: protocols and applications. PCR Methods Appl 1995;4:S151-67.

77 Pignatelli M, Liu D, Nasim MM, Stamp GW, Hirano S, Takeichi M. Morphoregulatory activities of $E$ cadherin and beta 1 integrins in colorectal tumour cells. $\mathrm{Br} \mathcal{f}$ Cancer 1992;66:629-34.

78 De Bruin PAF, Griffioen G, Verspaget HW, et al. Plasminogen activator profiles in neoplastic tissues of the human colon. Cancer Res 1988;48:4520-4.

79 Sier CFM, Vloedgraven HJM, Griffioen G, et al. Plasminogen activators and inhibitor type 1 in neoplastic colonic tissue from patients with familial adenomatous polyposis. $\mathrm{Br}$ f Cancer 1995;71:393-6.

80 MacDonald NJ, de la Rosa A, Steeg PS. The potential roles of $\mathrm{nm} 23$ in cancer metastasis and cellular differentiation. Eur $\mathcal{F}$ Cancer 1995;31A:1096-100.

81 Martinez JA, Prevot S, Nordlinger B, et al. Overexpression of nm23 H1 and nm23 H2 genes in colorectal carcinomas and loss of $\mathrm{nm} 23 \mathrm{H1}$ expression in advanced tumour stages. Gut 1995;37:712-20.

82 Iacopetta B, DiGrandi S, Dix B, Haig C, Soong R, House A. Loss of heterozygosity of tumour suppressor gene loci in human colorectal carcinoma. Eur f Cancer 1994;30A:66470

83 Cawkwell L, Lewis FA, Quirke P. Frequency of allele loss of DCC, p53, RBI, WT1, NF1, NM23 and APC/MCC in colorectal cancer assayed by fluorescent multiplex polymerase chain reaction. $\mathrm{Br} \mathcal{F}$ Cancer 1994;70:813-18.

84 Campo E, Miquel R, Jares P, et al. Prognostic significance of the loss of heterozygosity of $\mathrm{nm} 23 \mathrm{~h} 1$ and $\mathrm{p} 53$ genes in human colorectal carcinomas. Cancer 1994;73:2913-21.

85 Ichikawa W. Positive relationship between expression of CD44 and hepatic metastases in colorectal cancer. Pathobiology 1994;62:172-9.

86 Vogelstein B, Fearon ER, Kern SE, Hamilton SR, Preisinger AC, Nakamura Y, et al. Allelotype of colorectal carcinomas. Science 1989;244:207-11.

87 Gerdes H, Chen Q, Elahi AH, Sircar A, Goldberg E, Winawer $\mathrm{D}$, et al. Recurrent deletions involving chromosomes $1,5,17$, and 18 in colorectal carcinoma: possible role in biological and clinical behavior of tumors. Anticancer Res 1995;15:13-24.

88 Laurent-Puig P, Olschwang S, Delattre O, Remvikos Y, Asselain B, Melot T, et al. Survival and acquired genetic alterations in colorectal cancer Gastroenterology 1992;102: $1136-41$

89 Cohn KH, Ornstein DL, Wang F, LaPaix FD, Phipps K Edelsberg $\mathrm{C}$, et al. The significance of allelic deletions and aneuploidy in colorectal carcinoma. Results of a 5 year follow up study. Cancer 1997;79:233-44.

90 Kern SE, Fearon ER, Tersmette KW, Enterline JP, Leppert $\mathrm{M}$, Nakamura Y, et al. Allelic loss in colorectal carcinoma. ¥AMA 1989;261:3099-103.

91 Khine K, Smith DR, Goh HS. High frequency of allelic deletion on chromosome 17p in advanced colorectal cancer. Cancer 1994;73:28-35.

92 Purdie CA, Piris J, Bird CC, Wyllie AH. 17q allele loss is associated with lymph node metastasis in locally aggressive human colorectal cancer. F Pathol 1995;175:297-302.

93 Kelemen PR, Yaremko ML, Kim AH, Montag A, Michelassi $\mathrm{F}$, Westbrook CA. Loss of heterozygosity in $8 \mathrm{p}$ is associated vith microinvasion in colorectal carcinoma. Genes Chromosomes Cancer 1994;11:195-8.

94 Gustafson CE, Young J, Leggett B, Searle J, ChenevixTrench G. Loss of heterozygosity on the long arm of chromosome 11 in colorectal tumours. $\mathrm{Br} \mathcal{F}$ Cancer 1994;70 395-7.

95 Finkelstein SD, Sayegh R, Christensen S, Swalsky PA Genotypic classification of colorectal adenocarcinoma. Biologic behavior correlates with $\mathrm{K}$ ras 2 mutation type. Cancer 1993;71:3827-38.

96 Moerkerk P, Arends JW, van Driel M, de Bruine A, de Goeij $\mathrm{A}$, ten Kate J. Type and number of $\mathrm{Ki}$ ras point mutations relate to stage of human colorectal cancer. Cancer Res 1994;54:3376-8.

97 Span M, Moerkerk PT, De Goeij AF, Arends JW. A detailed analysis of $\mathrm{K}$ ras point mutations in relation to tumor progression and survival in

98 Kastrinakis WV, Ramchurren N, Maggard M, Steele G Jr, Summerhayes IC. K ras status does not predict successful hepatic resection of colorectal cancer metastasis. Arch Surg hepatic resection

99 Benhattar J, Losi L, Chaubert P, Givel JC, Costa J. Prognostic significance of $\mathrm{K}$ ras mutations in colorectal carcinoma. Gastroenterology 1993;104:1044-8.

100 Pricolo VE, Finkelstein SD, Wu TT, Keller G, Bakker Swalsky PA, et al. Prognostic value of $\mathrm{p} 53$ and $\mathrm{K}$ ras 2 mutational analysis in stage III carcinoma of the colon. Am f Surg 1996;171:41-6.

101 Seeburg PH, Colby WW, Capon DJ, Goeddel DV, Levinson AD. Biological properties of human $\mathrm{c} \mathrm{Ha}$ ras 1 genes mutated at codon 12. Nature 1984;312:71-5. 
102 Bos JL, Toksoz D, Marshall CJ, Verlaan de Vries M, Veeneman $\mathrm{GH}$, van der $\mathrm{Eb} \mathrm{AJ}$, et al. Amino acid substitutions codon 13 of the $\mathrm{N}$ ras oncogene in human acute myeloid leukaemia. Nature 1985;315:726-30.

103 Fasano O, Aldrich T, Tamanoi F, Taparowsky E, Furth M, Wigler $M$. Analysis of the transforming potential of the human $\mathrm{H}$ ras gene by random mutagenesis. Proc Natl Acad Sci USA 1984;81:4008-12.

104 Manne V, Bekesi E, Kung HF. Ha ras proteins exhibit GTPase activity: point mutations that activate Ha ras gene
products result in decreased GTPase activity. Proc Natl products result in decreased
Acad Sci USA 1985;82:376-80.

105 Der CJ, Finkel T, Cooper GM. Biological and biochemical properties of human rasH genes mutated at codon 61 . Cell 1986;44:167-76.

106 McGrath JP, Capon DJ, Goeddel DV, Levinson AD. Comparative biochemical properties of normal and activated human ras p21 protein. Nature 1984;310:644-9.

107 Shibata D, Reale MA, Lavin P, Silverman M, Fearon ER, Steele G Jr, et al. The DCC protein and prognosis in colorSteele G Jr, et al. The DCC protein and progno
ectal cancer. $N$ Engl f Med 1996;335:1727-32.

108 Sankila R, Aaltonen LA, Jarvinen HJ, Mecklin JP. Better survival rates in patients with MLH1 associated hereditar cancer. Gastroenterology 1996;110:682-7.

109 Fujita S, Moriya Y, Sugihara K, Akasu T, Ushio K. Prognosis of hereditary nonpolyposis colorectal cancer (HNPCC) and the role of Japanese criteria for HNPCC. fpn f Clin Oncol 1996;26:351-5.

110 Ishimaru G, Adachi J, Shiseki M, Yamaguchi N, Muto T, Yokota J. Microsatellite instability in primary and metastatic colorectal cancers. Int $\mathcal{F}$ Cancer 1995;64:153-7.

$111 \mathrm{Bubb}$ VJ, Curtis LJ, Cunningham C, Dunlop MG Carothers AD, Morris RG, et al. Microsatellite instability and the role of $\mathrm{hMSH} 2$ in sporadic colorectal cancer. Oncogene 1996;12:2641-9

112 Remvikos Y, Tominaga O, Hammel P, Laurent Puig P, Salmon RJ, Dutrillaux B, et al. Increased p53 protein content of colorectal tumours correlates with poor survival. $\mathrm{Br}$ $f$ Cancer 1992;66:758-64.

113 Kressner U, Lindmark G, Gerdin B, Pahlman L, Glimelius B. Immunohistological p53 staining is of limited value in the staging and prognostic prediction of colorectal cancer Anticancer Res 1996;16:951-7.

114 Diez M, Enriquez JM, Camunas J, Gonzalez A, Gutierre A, Muguerza JM, et al. Prediction of recurrence in B C stages of colorectal cancer by p 53 nuclear overexpression in comparison with standard pathological features. Eur $\mathcal{F}$ Surg Oncol 1995;21:635-9.

115 Grewal H, Guillem JG, Klimstra DS, Cohen AM. p5 nuclear overexpression may hot be an independent prognostic marker in eart

116 Lazaris AC, Theodoropoulos GE, Anastassopoulos P, Nakopoulou L, Panoussopoulos D, Papadimitriou K. Prognostic significance of $\mathrm{p} 53$ and c erbB 2 immunohistochemical evaluation in colorectal adenocarcinoma. Histo Histopathol 1995;3:661-8.

117 Houbiers JG, van der Burg SH, van de Watering LM, Tollenaar RA, Brand A, van de Velde CJ, et al. Antibodies aainst $\mathrm{p} 53$ are tal cancer. $\mathrm{Br} \mathcal{F}$ Cancer $1995 ; 72.637$ prog
118 Tomoda H, Kakeji Y. Immunohistochemical analysis of p53 in colorectal cancer regarding clinicopathological correlation and prognostic significance. F Surg Oncol 1995;58 125-8.

119 Morrin M, Kelly M, Barrett N, Delaney P. Mutations of K ras and p53 genes in colorectal cancer and their prognostic significance. Gut 1994;35:1627-31.

120 Zeng ZS, Sarkis AS, Zhang ZF, Klimstra DS, Charytonowicz E, Guillem JG, et al. p53 nuclear overexpression: an independent predictor of survival in lymph node positive? colorectal cancer patients. $\mathcal{F}$ Clin Oncol 1994;12:2043-50

121 Tanaka M, Omura K, Watanabe Y, Oda Y, Nakanishi I. Prognostic factors of colorectal cancer: $\mathrm{K}$ ras mutation overexpression of the $\mathrm{p} 53$ protein, and cell proliferative activity. I Surg Oncol 1994;57:57-64.

122 Suzuki H, Matsumoto K, Koide A, Tada T, Fujino I, Okuda A, et al. Correlation of $\mathrm{p} 53$ with the clinicopathologic features and prognosis of colorectal adenocarcinoma. logic features and prognosis
Surg Today 1994;24:85-7.

123 Nathanson SD, Linden MD, Tender P, Zarbo RJ, Jacobsen कै $\mathrm{G}$, Nelson LT. Relationship among p53, stage, and prognosis of large bowel cancer. Dis Colon Rectum 1994;37:527-O 34

124 Bell SM, Scott N, Cross D, Sagar P, Lewis FA, Blair GE, et al. Prognostic value of $\mathrm{p} 53$ overexpression and c $\mathrm{Ki}$ ras gene mutations in colorectal cancer. Gastroenterology 1993;104: Э 57-64.

125 Yamaguchi A, Kurosaka Y, Fushida S, Kanno M, Yonemura Y, Miwa K, et al. Expression of p53 protein in colorectal cancer and its relationship to short term prognosis. Cancer 1992;70:2778-84.

126 Goh HS, Yao J, Smith DR. p53 point mutation and $\infty$ survival in colorectal cancer patients. Cancer Res 1995;55:

, Laurent Puig P, Olschwang S, Jego N, Asselain , Remvikos Y, et al. Association of p53 mutations with 106:42-8.

128 Bertorelle R, Esposito G, Del Mistro A, Belluco C, Nitti D, Lise $\mathrm{M}$, ot al. Association of p53 gene and protein alterations with metastases in colorectal cancer. Am $\mathcal{F}$ Surg $\mathbb{\complement}$ Pathol 1995;19:463-7.

129 Kastrinakis WV, Ramchurren N, Rieger KM, Hess DT, $\vec{\bullet}$ Loda $M$, Steele $G$, et al. Increased incidence of p53 mutations is associated with hepatic metastasis in colorectal. neoplastic progression. Oncogene 1995;11:647-52.

130 Goh HS, Chan CS, Khine K, Smith DR. p53 and behaviour of colorectal cancer. Lancet 1994;344:233-4.

131 Bosari S, Viale G, Roncalli M, Graziani D, Borsani G, Lee $\mathrm{AK}$, et al. $\mathrm{p} 53$ gene mutations, $\mathrm{p} 53$ protein accumulation and compartmentalization in colorectal adenocarcinoma. Am f Pathol 1995;147:790-8.

132 Smith DR, Ji CY, Goh HS. Prognostic significance of $\mathrm{p} 53$ overexpression and mutation in colorectal adenocarcinomas. Br f Cancer 1996;74:216-23.

133 Steeg PS, Abrams JS. Cancer prognostics: past, present and p27. Nat Med 1997;3:152-4

134 Loda M, Cukor B, Tam SW, Lavin P, Fiorentino M, Draetta GF, et al. Increased proteasome dependent degradation of the cyclin dependandent kinase inhibitor $\mathrm{p} 27$ in aggressive colorectal carcinomas. Nat Med 1997;3:231 4. 